\title{
NATALiTy AND Biopolitics in HANNAH ARENDT
}

\author{
Miguel Vatter \\ Pontificia Universidad Católica de Chile
}

\begin{abstract}
Resumen
Este ensayo discute la génesis del concepto de la natalidad en Arendt, y las razones que la llevaron a proclamar la natalidad como un concepto fundamental del pensamiento político. El trabajo argumenta en contra de la tesis comúnmente aceptada según la cual Arendt habría sacado el concepto de natalidad de la analítica existencial de Heidegger. Por lo contrario, el escrito propone que el discurso arendtiano sobre la natalidad debe ser visto como parte de un discurso sobre la bio-política, y que está basado sobre un concepto de vida anti-Heideggeriano. El pensamiento político de Arendt es una especie de bio-política que contrasta al totalitarismo en su propio terreno, es decir, identificando los aspectos de la vida que oponen resistencia al proyecto totalitario de dominio absoluto sobre la vida.
\end{abstract}

Abstract

This essay discusses the genesis of Arendt's concept of natality, and the reasons that led her to claim natality as a fundamental concept of political thought. The essay argues against the widespread thesis that Arendt took her idea of natality from Heidegger's existential analysis of human life. It argues, instead, that Arendt's account of natality should be situated within the discourse of bio-politics, and that it is based on a conception of life that is anti-Heideggerian. Arendt's political thought is a species of bio-politics that counters totalitarianism on its own terrain, namely, by identifying what in life poses a resistance to the totalitarian project of attaining total domination over life.

\section{PALABRAS CLAVE • Arendt • Heidegger • Natalidad • Libertad • Biopolítica • Totalitarismos}

\section{THE GENESIS OF ARENDT'S CONCEPT OF NATALITY}

Arendt calls natality, defined as the fact that each human life begins with birth, the "central category of political thought" (Arendt, 1958: 9). "Because they are initium, newcomers and beginners by virtue of birth, men take initiative, are prompted into action" (Arendt, 1958: 177). The human capacity to act freely is said to be "ontologically rooted" in this "fact of natality" (Arendt, 1958: 177). There is something very puzzling about identifying the root of human freedom in the condition of natality. Why should birth, of all things, condition human beings to live freely? The puzzlement only gets more troublesome if one considers that Arendt appears to argue, throughout her work, that action, and so politics, are not biologically conditioned. ${ }^{1}$ For Arendt, it is labor, not

1 Arendt is often, and in a sense rightly, seen as an anti-biologistic thinker in the secondary literature, see (Ricoeur, 1983); (Heller, 1994); (Savarino, 2003). Beiner speaks of the "anti-naturalistic philosophy" of Arendt (Beiner, 1984: 358) and opposes the "miracle" of action to "something given naturally" (Beiner, 1984: 360). But this assumption has also often had the unfortunate consequence of leading interpreters to abstract Arendt's concept of natality from her complex theory of life (Kristeva, 2000). 
political action, which reflects the dependency of human beings on biological processes that are not under their control, and that they experience as necessity. ${ }^{2}$ But if Arendt's political thought is so "anti-biological", then why does she root human freedom in birth? Unless one comes to terms with this paradox, the sense of Arendt's political thought will remain unclear. This essay tries to resolve the puzzle by arguing that through her concept of natality, Arendt seeks to reconnect the essence of human freedom to biological life so as to gain a new aim for politics. Politics should no longer depend on the reduction of life to the sphere of necessity, as has been the case throughout the main tradition of western political thought (Arendt, 2005: 40-92). Instead, politics should be thought of as the freedom of life itself.

In most recent discussions of Arendt's political thought, the human condition of natality, together with the human condition of plurality to which it is closely connected, ${ }^{3}$ is invariably mentioned on the way to treating her conception of action. Yet natality as such is hardly ever discussed in any significant detail, as if the relation between natality and action were either too obscure or, on the contrary, simply self-evident (Beiner, 1984; Benhabib, 1996; Canovan, 1994; Pitkin, 1998; Villa, 1996). Arendt herself, after a certain moment, began to repeatedly and obsessively gesture towards this relation, always drawing support from one citation drawn from St. Augustine, in which the Christian author seems to indicate that the divine creation of Man was for the sake of the human capacity to begin. ${ }^{4}$ But Arendt never submitted natality, either in the relation that it has to biological life, or in the relation that it has to divine creation, to a sustained analysis. Along with her doctrine on "judging", natality is the other keystone of her philosophical edifice, of which there remains nothing more than a few, fragmentary textual allusions. ${ }^{5}$

In the current literature dedicated specifically to the concept of natality there is no extended discussion as to when exactly, and in what precise context, Arendt began to employ this concept (Bowen-Moore 1989; Collin 1999; Collin 2000; Durst 2004; Markell 2006). A few scholars have pointed out that the term "natality", or something close to it, is found in Heidegger's Sein und Zeit. ${ }^{6}$ Heidegger, in fact, does argue that death is "only one end" enclosing human existence (Dasein); the "other 'end' is the 'beginning', the 'birth'"(Heidegger, 1986: 373) such that human existence can also be characterized by a "Sein zum Anfang" (being-towards-beginning) and not only by its "Sein zum Tode" (being-towards-death). Heidegger concludes his only treatment of birth found in his work with the claim that

"The human condition of labor is life itself". (Arendt, 1958: 7) See also (Arendt, 1958: 98-99).

Arendt defines "the human condition of plurality" as "the fact that men, not Man, live on the earth and inhabit the world" (Arendt, 1958: 7).

$4 \quad$ Arendt cites Augustine in connection with the idea that natality is the condition of human freedom in (Arendt, 1977: 167; Arendt, 1978: II,217) (Arendt, 1973: II, 108-110; Arendt, 1990: 212-213, 215).

5 The best account of the significance of these lacunae for the interpretation of Arendt's system as a whole remains (Forti 1996), but see also (Savarino, 1997).

6 There is a brief, but important discussion of the possible Heideggerian origin of the natality in (Schürmann, 1996: 68, n.33). (Collin, 1999) discusses Schürmann's interpretation, and in general takes up the paradox of Arendt's concept of natality, seemingly embedded in nature yet anti-natural (Collin, 1999: 99). Bowen-Moore also thinks that Arendt's treatment of "natality as a philosophical theme" is of Heideggerian provenance (Bowen-Moore, 1989: 2), and is intended to counteract Heidegger's emphasis on mortality. (Szankay, 1995: 6) problematizes the "philosophical" understanding of the concept of natality, but nonetheless also separates it from both "anthropological" and "biological" category. (Brunkhorst, 1999) mentions that the term "natality" seems to correspond to Heidegger's discussion of birth found in section 72 of Sein und Zeit (Heidegger, 1983: 374). (Villa, 1996) and (Taminiaux, 1985), though, ignore this Heideggerian origin in their discussions of Arendt's relation to Heidegger's thought. 
"factical Dasein exists natively [das faktische Dasein existiert gebürtig] and natively it dies also already in the sense of being-towards-death [und gebürtig stirbt es auch schon im Sinne des Seins zum Tode....] In the unity of thrownness and fleeting, that is, anticipatory beingtowards-death, birth and death existentially 'hang together' [In der Einheit von Geworfenheit und flüchtigen, bzw. Vorlaufendem Sein zum Tode 'hängen' Geburt und Tod daseinsmässig 'zusammen']. As care Dasein is this 'in-between' [Als Sorge ist das Dasein das 'Zwischen']" (Heidegger, 1986: 374).

Although in the above passage Heidegger does seem to bring together the ideas of birth and of the in-between that will turn out to be fundamental for Arendt's mature concept of freedom, which I discuss below, there are nonetheless good reasons to doubt that Heidegger's text is the sole, immediate or even decisive inspiration for Arendt's concept of natality. In the first place the term "natality" does not actually appear in Heidegger's text, neither as Gebürtigkeit (Schürmann's translation of natality) nor as Gebürtlichkeit (standard German translation for Arendt's term natality). Heidegger uses only the adjective gebürtig (native), which he employs adverbially, but he does not assign to birth the capacity or faculty (designated in German by -keit, in English by -ity) that Arendt assigns to it. Indeed, when Arendt first begins to employ the term in her essays, she does so in English, and, on the evidence drawn from her recently published Denktagebuch (her notebooks dating from 1950 onwards, mostly written in German), she seems to translate it back from English into German as "Natalität” (Arendt, 2002: 461).

Moreover, in Sein und Zeit Heidegger offers no further analysis of his concept of "being-towards-beginning" (Sein zum Anfang), but instead quickly returns to asserting the priority of being-towards-death for the self-understanding of human existence. This priority of death, is precisely what Arendt contested already in her 1929 dissertation on Augustine's theory of love. Most interpreters have all too rashly identified this as being written under the influence of Heidegger, basing this illation more on the well-known and much commented relationship to her university teacher than on a serious study of the dissertation itself (Arendt, 1996). In reality, the dissertation seems to demonstrate, if anything, that Arendt rejected from the start the basic foundations of Heidegger's analytic of Dasein.

The dissertation investigates the possibility of grounding the Christian call to "love thy neighbor as thyself" in the "love of God". It sets out to demonstrate that two irreconcilable conceptions of love or caritas co-exist in Augustine's corpus, both of which, ultimately, stand in tension with the possibility of establishing a meaningful "love of the neighbor" as the human other. The first idea of caritas is modeled on the idea of desire as appetite: here the love of God is understood in terms of the desire to acquire an object that cannot possibly be "lost" because it shares nothing with the transience of worldly things. According to Arendt, this idea of caritas requires "self-forgetfulness and complete denial of human existence... [and] makes the central Christian demand to love one's neighbor as oneself well nigh impossible" (Arendt, 1996: 30).

The second account of love that Arendt finds in Augustine takes as its basis the dualism Creatorcreature. It is in discussing this second idea of caritas that Arendt explicitly detaches herself from and criticizes Heidegger's analytic of existence. In Arendt's reading of Augustine, the Creatorcreature distinction is set within the context of the possibility of achieving a "happy life". This preoccupation was completely foreign to Heidegger. On the other hand, it was central to the entire development of Walter Benjamin's thought, from the early programmatic texts on the philosophy 
of language through the late theses on history. ${ }^{7}$ For Arendt, the source of this idea of happiness is our "memory": "the knowledge of the possible existence of the happy life is given in pure consciousness prior to all experience, and it guarantees our recognizing the happy life whenever we should encounter it" (Arendt, 1996: 46). Memory here is concerned with "safeguarding" a past that was never a present, something that was never experienced; the past constituted by a "transcendent and transmundane ... origin of human existence as such", radically opposed to a transcendence oriented towards "goals" and which has the future as its fundamental temporal horizon (Arendt, 1996: 48). Heidegger's discussion of birth and death in Sein und Zeit occurs within his deduction of the "historicity" (Geschichtlichkeit) of human existence. In this context, Heidegger argues that "destiny" and the "future" are fundamental for the historicity of human existence. Arendt's own treatment of historicity, by contrast, is clearly oriented, already in the dissertation on Augustine, toward an idea of "freedom" that is inseparable from the recovery of, or return to such an "absolute past": "it is memory and not expectation (for instance, the expectation of death as in Heidegger's approach) that gives unity and wholeness to human existence" (Arendt, 1996: 55-56). In her later political thought, the experience of origins would be fundamental for the development of her theory of revolutionary legitimacy (Arendt, 1977, 1990).

The concept of recollection that Arendt teases out of Augustine offers, according to her, the basis for a different conception of love -one not based on appetite. In remembering the origin, man is oriented towards "loving" God's love (for man), as manifest in Creation, and not simply oriented towards "love of God" (where God is a possible object of desire). In this other conception of love, what is loved by man is the "original interconnectedness of either man and God or man and world" (Arendt, 1996: 30). This interconnectedness will later receive the name of "natality", and it will be christened through the famous quotation drawn from Augustine's City of God. But in her original dissertation, neither this citation nor natality are to be found. In fact, Arendt only inserts the pertinent citation from Augustine ex post facto, when, in the period from 1958 through 1964, she revises parts of her dissertation (especially the section dealing with Creation) with the intent to republish it in an English translation (Arendt, 1996: 132). ${ }^{8}$ order should be erected on the idea of happiness. The relation of this order to the messianic is one of the essential teachings of the philosophy of history.... For in happiness all that is earthly seeks its downfall.... The spiritual restitution in integrum, which introduces immortality, corresponds to a worldly restitution that leads to an eternity of downfall, and the rhythm of this eternally transient worldly existence... the rhythm of messianic nature, is happiness" (Benjamin, 2002: 305-6). The most condensed formulation of this motif in Benjamin appears in the second of his theses on history, a typed manuscript of which Arendt brought with her from Paris to New York: "our image of happiness is indissolubly bound up with the image of redemption. The same applies to our view of the past, which is the concern of history. The past carries with it a temporal index by which it is referred to redemption. There is a secret agreement between past generations and the present one. Our coming was expected on earth" (Benjamin, 1968: 254). On the foundation of political philosophy on the "happy life" in this Benjaminian sense, see also (Agamben, 2000: 113). Villa's claim that "the spirit of Benjamin, not Heidegger, informs her search for hidden treasures", though true, remains completely undeveloped and indeed stands in unresolved tension with his principal thesis according to which Arendt's "ontological approach to human freedom... points unequivocally toward Heidegger and specifically toward Being and Time" (Villa, 1996: 119). In a companion piece to this article, I explore at length the importance of Benjamin's work for the development of Arendt's thought.

8 In her 1929 discussion of Augustine's theory of creation, Arendt emphasizes Augustine's idea that "man is something so long as he adheres to him by whom he was made a man". To which Arendt glosses: "This adhesion is not a matter of will and free decision; it expresses a dependence inherent in the fact of createdness". (Arendt, 1996: 51) The point, for Arendt, is to distinguish a false "dependence" of man to its desired objects, which orients action towards 
More problematic still, for those interpreters who insist on the Heideggerian origin of natality, is that in Arendt's discussion of the second conception of love she mounts her sharpest critique of Heidegger: "That man in his desire to be happy depends upon a notion of happiness that he could never experience in his earthly life, and that such a notion, moreover, should be the sole determinant of his earthly conduct, can only signify that human existence as such depends on something outside the human condition as we know and experience it.... This 'outside the human condition' actually means before human existence. Therefore the Creator is both outside and before man. The Creator is in man only by virtue of man's memory" (Arendt, 1996: 49). This is the first time Arendt mentions the idea of "human condition" that would later give the title for her most important work, and she uses the term "condition" to mean the relation that human existence has to an Other that remains radically "outside" of this condition. "The creature in its createdness derives its sense of meaningfulness from a source that precedes its creation, that is, from the Maker who made it.... The very fact that man has not made himself but was created implies that the meaningfulness of human existence both lies outside itself and antedates it. Createdness (creatum esse) means that essence and existence are not the same.... Hence to 'return to God' is actually the only way in which a created thing can 'return to itself'" (Arendt, 1996: 50). The implicit rejection of the position of Heidegger (for whom human existence is defined as a function of assigning "meaning" to Being) as well as of German existentialism (for which human existence is defined precisely by the identity of essence and existence) could not be clearer. ${ }^{9}$ What changes from 1929 to 1958, the year of publication of The Human Condition, is that the relation of human existence to what is outside it and gives it meaning ceases to be called the "fact" of Creation and becomes "the fact of natality", where the accent falls more on the connection with the phenomenon of life than on the connection with the phenomenon of creation.

With the recent publication of the fragments from the 1950s entitled Was ist Politik?, as well as her work diaries (Denktagebuch) for the same years, one can attempt to reconstruct with some historical precision the exact genesis of the concept of natality in Arendt's thought. Prior to and including the first edition of Origins of Totalitarianism Arendt had not employed this concept. After finishing that book, starting in 1950, her work diaries and fragmentary texts are entirely dedicated to rethinking about politics starting from the fundamental distinction between "men", who are always in the plural, and "Man", the single species. Her central working hypothesis is that the entire western tradition of political thought has ignored this distinction, attempting to think politics

death and the future, from a true "dependence" of man on an "origin", i.e., divine creation, that "relies exclusively on rememberance and refers back to the past" (Arendt, 1996: 51). It is only the latter dependence that "frees" human action from teleology and allows it to be novitas. Only in the 1964-5 revision of her old manuscript does she add: “To put it differently, the decisive fact determining man as a conscious, remembering being is birth or 'natality', that is, the fact that we have entered the world through birth. The decisive fact determining man as a desiring being was death or mortality [clear allusion to Heidegger's standpoint in Sein und Zeit/MV].... In contrast, gratitude for life having being given at all is the spring of rememberance, for a life is cherished even in misery.... This will to be under all circumstances is the hallmark of man's attachment to the transmundane source of his existence" (Arendt, 1996: 51). Here one sees the decisive shift between the original version of 1929 and the revised version thirty years later: the "fact of createdness" has becomes the "fact" of natality. Both facts determine a condition of human existence that is not the object of the will because it depends on creation. There follows Arendt's revised conclusion: "Hence, it was for the sake of novitas, in a sense, that man was created. Since man can know, be conscious of, and remember his 'beginning' or his origin, he is able to act as a beginner and enact the story of mankind" (Arendt, 1996: 55).

$9 \quad$ In Sein und Zeit Heidegger writes: “Das 'Wasen' des Daseins liegt in seiner Existenz” (Heidegger, 1986: 42). Arend will discuss and criticize these positions immediately after the war, in her essays "What is Existential Philosophy?" and "French Existentialism" (Arendt, 1994: 163-196). 
from the identity of all human beings qua specimens of the same species, rather than from their "original differentiation". This avoidance of plurality is found both in the Aristotelian conception of man as zoon politikon, which makes politics inhere in human nature, and in the Christian conception of man as created in the image of the One God, which orients politics towards omnipotence. And it climaxes in modern philosophies of history, where human plurality is fused into the idea of humanity as the subject of History (Arendt, 2003: 9-11) (Arendt, 2005: 94-95). To this western political tradition, Arendt's simply objection is simply that "man is apolitical. Politics arises between men, and so quite outside of man. There is therefore no political substance. Politics arises in what lies between men and is established as relationships" (Arendt, 2005: 95).

But at this point, as one can see from Fragment 1 of Was ist Politik?, dated August 1950, the plurality of men is still considered "a human, earthly product, the product of human nature", in opposition to the "fact" that "God created man" (Arendt, 2005: 93). "Man, as philosophy and theology know him, exists - or is realized - in politics only in the equal rights that those who are most different guarantee for each other. This voluntary guarantee of, and concession to, a claim of legal equality recognizes the plurality of men, who can thank themselves for their plurality and the creator of man for their existence" (Arendt, 2005: 94). Plurality has not yet found its definitive ontological placement: it remains a human product, analogous to the sense in which human political organizations are human products. What human beings can have in common are human rights, for these belong to every man in so far as he or she is a member of the species "man", itself a creation of God. Human rights, in this sense, are pre-political for Arendt. There is here no way to think about what men, in the plural, have "in common" as the "absolute differentiation" of every singular individual, as what makes each individual irreducible to a specimen, to a member of the species. "God's creation of the plurality of men is embodied in the absolute difference of all men from one another, which is greater than the relative difference among peoples, nations, or races. But in that case, there is in fact no role for politics. From the every start, politics organizes those who are absolutely different with a view to their relative equality and in contradistinction to their relative differences" (Arendt, 2005: 96). Absolute difference is here not yet immediately political. Likewise, the dimension of the political, the in-between of a plurality of men, is still thought of as an object of human practice, something that can be "made" in some sense or other (Arendt, says "human, earthly product"). The in-between is not yet ontologically rooted in a "condition" about which men can ultimately do nothing about, a condition that limits, a priori, its manipulability.

The first breakthrough seems to be datable to an entry in the Denktagebuch dated April 1951. Arendt comments on two passages found side by side in Augustine's City of God, where the creation of man is distinguished from the creation of animals. The first passage concerns Augustine's idea that God "started... with one man, whom he created as the first man... instead of starting with many" whereas, in the case of animals, "he commanded many to come into existence at once" (Augustine, 1984: XII, 22). The second passage is the famous citation: "to provide that beginning, a man was created, before whom no man ever existed" (Augustine, 1984: XII, 21). Arendt then comments on these passages:

"with men came into the world the beginning. On this rests the sanctity (die Heiligkeit) of human spontaneity. Totalitarian extermination of men as men is the extermination of their spontaneity. This means at the same time the reversal of creation as creation, as to-have-made-a-beginning [die Rückgängigmachung der Schöpfung als Schöpfung, als Einen- 
Anfang-gesetzt-Haben]. Maybe here is the connection between the attempt to destroy men and the attempt to destroy nature" (Arendt, 2002: 66).

What makes this comment highly significant is that the plurality of men that the western political tradition resists acknowledging is due to their animality, because, if one follows Augustine's text, only animals were created in the plural, rather than starting from one specimen ("the first man"). But, on the other hand, the existence of spontaneity, again following Augustine, is due to God having created man, not animals. Only if animal life is directly connected to the capacity to begin, as Arendt will connect them later through the concept of natality, does it make sense to assume that "the attempt to destroy men" is fundamentally connected to the "attempt to destroy nature".

The concept of natality makes its official entrance only two years after, in 1953, the year she delivers her unpublished Geuss lectures on "Karl Marx and the Tradition of Political Thought" at Princeton, ${ }^{10}$ and publishes "Ideology and Terror", which would become the last chapter of the second, 1958 edition of Origins of Totalitarianism. The manuscript on Marx contains no reference to natality or to Augustine, but on the contrary has much to say about the category of labor as indicative of the insurmountable animality of man. Natality and the Augustine citation first appears in "Ideology and Terror", where Arendt thematizes the connection between action, natality and createdness. "Beginning... is the supreme capacity of man; politically, it is identical with man's freedom. Initium ut esset homo creatus est - 'that a beginning be made man was created' said Augustine. This beginning is guaranteed by each new birth; it is indeed every man" (Arendt, 1973: 478-9).

The available textual evidence, then, seems to indicate that Arendt begins to use the concept of natality only after the publication in 1951 of the first edition of her study on The Origins of Totalitarianism. In a letter to Jaspers of that year she writes that the evil of totalitarianism is condensed in the belief that the individuals of the species "man" are superfluous for the realization of the species (Arendt, 1992: 166). ${ }^{11}$ Soon thereafter she begins to theorize a new, counter-totalitarian politics that would take the birth of just these "superfluous" individuals, in their radical diversity from each other, as its fundamental principle. ${ }^{12}$

\section{ARENDT'S POLITICAL THOUGHT AS BIOPOLITICS}

If the above conjectures as to the genesis of Arendt's concept of natality are correct and she did begin to make use of the concept of natality only after having formulated the main lines of her

10 Parts of which are now found in (Arendt, 2005).

11 "What radical evil is I do not know, but it seems to me it somehow has to do with the following phenomenon: making human beings as human beings superfluous (not using them as means to an end, which leaves their essence as humans untouched and impinges only on their human dignity; rather, making them superfluous as human beings). This happens as soon as all unpredictability -which, in human beings, is the equivalent of spontaneity-is eliminated. And all this in turn arises from -or, better, goes along with- the delusion of the omnipotence (not simply with the lust for power) of an individual man. If an individual man qua man were omnipotent, then there is in fact no reason why men in the plural should exist at all". (Letter to Jaspers, March 4, 1951). The idea that "making men superfluous" is definitive for the totalitarian phenomenon is also found in (Arendt, 1973: 459).

12 Ricoeur calls Arendt's new theorization of the political an act of "resistance" to the "new form of government", i.e., totalitarian government (Ricoeur, 1983: 14). 
interpretation of totalitarianism, then this would indicate that through this concept Arendt not only wanted to formulate a counter-totalitarian politics, but one that would be as much a politics of life as totalitarianism was a politics of death. On this hypothesis, it would be simply false to suppose that Arendt wanted to counter totalitarian politics by separating her conception of politics from all connection to biological life. Totalitarian politics, based on the extermination of "superfluous" individuals, and Arendtian politics, based on the revaluation of the birth and plurality of precisely such individuals, would then both belong within the discursive matrix or episteme that Foucault would much later call "biopolitics" (Foucault, 1990; Foucault, 2004). By interpreting totalitarianism as a bio-political phenomenon, one is also in a position to better understand what Arendt was trying to achieve with her category of natality. ${ }^{13}$

Foucault defines biopolitics as that transformation in the idea of politics which took place in early modernity, by which politics came to be defined as a "power over life", as the domination over life achieved through the control of the life process itself. Foucault argues that until the baroque age, the preservation of biological life, much like the capacity to speak, had been considered merely the preconditions, not the ends, of a political way of life. For Aristotle, politics presupposes that man is a living being (zoon) who speaks (logon echon), but the end of politics was "living well" (eu zen) not "mere living" (tou zen): happiness (eudaimonia), not life itself (Aristotle, 1988: 1252b: 30; Foucault, 1990: 143).

According to Foucault, totalitarianism is one potential outcome of the modern redirecting of politics towards species life. This is because the other side of a power over life is the power to let die: totalitarianism is one manifestation of the politics of death which is an always immanent potential of biopolitics (Foucault, 1990: 138-139). The power to "disallow life to the point of death" (Foucault, 1990: 138) becomes the index of the degree to which life has come under human control and domination. This Foucaultian intuition merely expresses theoretically what Primo Levi, among others, experienced as the real "purpose" of totalitarian regimes, irrespective of their ideologies: the "resolution of others to annihilate us first as men in order to kill us more slowly afterwards" (Levi, 1996: 51). The Lager is "a gigantic biological and social experiment" (Levi, 1996: 87) in which human life is de-humanized in order to create as end-product the "Muselmänner, the drowned... an anonymous mass, continually renewed and always identical, of non-men who march and labour in silence, the divine spark dead within them, already too empty to really suffer. One hesitates to call them living: one hesitates to call their death death" (Levi, 1996: 90). In his recent work, Giorgio Agamben has referred to this de-humanized human life as "bare life" and the bearer of such life as homo sacer: somebody who can be killed without committing either murder or sacrilege because she has been expelled from the precincts of human and divine law, because her life is no longer recognized to be a human life (Agamben, 1998; Agamben, 1999). Arendt, of course, was familiar with "bare life" in this sense, having dedicated an entire chapter of Origins of Totalitarianism to discuss "the preparation of living corpses" (Arendt, 1973: 451) in the concentration and extermination camps, whose sole result was to 
achieve "total domination" through the destruction of the "uniqueness" and the "individuality" of human beings (Arendt, 1973: 455).

To anticipate somewhat my conclusion, Arendt's answer to the phenomenon of the systematic production of "bare life" in totalitarian regimes consists in basing a politics on the phenomenon of natality. Natality is a biopolitical concept that counters the "thanatopolitical" concept of bare life, a response to the politics of death implicit in modern biopolitics and realized, for the first time but certainly not for the last, in the totalitarian regimes of the $20^{\text {th }}$ century (Esposito, 2004: 115-158). Not for the last time: after all, it was during the 1950s that Arendt became convinced that totalitarianism is a new, but "essential" form of government, whose possibility therefore must correspond to some "basic experience" of human beings, and hence is inherently repeatable. The "basic experience" to which totalitarianism "responds" politically is that of "loneliness" (Arendt, 1973: 474).

Arendt's political thought after 1950 indicates that the negative consequences of biopolitics should be met by a positive biopolitics. Roberto Esposito has recently identified this dualism of biopolitical discourse, i.e., the fact that biopolitics divides into a "life-affirming" politics and a "life-denying" one (Esposito, 2004). But his own attempts to understand the grounds and logic of this dualism in what he calls the "paradigm of immunization" (Esposito, 2004: 41-77) seems insufficient to explain the variety of ways in which life always carries with it a double, antinomical function in biopolitical discourse. One can see the trace of this antinomical self-doubling of life in, for example, Freud's later dualism of fundamental drives (Eros and Thanatos) (Freud, 1961), in Foucault's distinction between sexuality and pleasures (Foucault, 1990), in Agamben's idea that "bare life" is "sacred" only when it comes under the form of the law, but otherwise has a redemptive function (Agamben, 2004); perhaps most importantly of all, in Benjamin's distinction between "mere life" and "that life which is identically present in earthly life, death, and afterlife (Benjamin, 1999: 249-252). In all these cases, if biological life can become the object (or, better, the target) ${ }^{14}$ of political control and domination in thanatopolitics, so also biological life must be capable of becoming the subject (or, perhaps better, the line of flight) ${ }^{15}$ of resistance to domination.

\section{ZOE AND BIOS: HUMANISM AND ANTI-HUMANISM IN ARENDT'S BIOPOLITICS}

In order to play this double biopolitical role, biological life needs to be reconceived as containing a caesura, a discontinuity within itself. On one side of this caesura, life is the politically passive object of domination; on the other side, it is the politically active subject of a new freedom. "Subject" here means literally sub-jectum, what is thrown-under as a condition for a new action. In Arendt, natality is the name for this sub-jectivity, for this being-thrown(-under) that provides the basis from which a self springs forth as revealed in its actions and words. ${ }^{16}$ In the following sections I show that Arendt's concept of natality is one of the names of this caesura of life within life. This

14 On the concept of "target" and "targeting" in relation to Benjamin, see (Weber, 2005).

15 I use this expression from Deleuze and Guattari to indicate that aspect of life in so far as it escapes, or avoids, being the "target" of domination (Deleuze, 1987).

16 This does not mean that natality corresponds to Heidegger's concept of Geworfenheit (thrownness) (Heidegger, 1986: 135), as claimed, all too quickly, in Benhabib (1996: 109) and Villa (1996: 141). 
caesura makes possible the transition from life as object of power to life as subject of freedom. Natality is the having-become of biological life: it refers to what may be called the "natural history" of life. The having-become of life is its pastness, or thrownness. This natural-historical dimension of life, for Arendt, refers life back to an origin that lies outside of life, an origin that receives the name of creation. At the same time, natality is constitutive of the sub-jectivity of life, and this in two senses: because it is the freedom of life, and because it is the condition for the selfhood on the human being and the history of its self-initiated actions.

To avoid misunderstandings in relation to the interpretative hypothesis I outline, it is important not to confuse the caesura of life figured by natality with the classical division of life into species life (zoe) and human life (bios), a division which also plays a role in Arendt's texts (Arendt, 1977: 42; 1958: 96-97). Undoubtedly, one of the strongest claims found in The Human Condition is the identification, critique and rejection of the historical reversal by which the bios politikos, the political life, took as its purpose the management of zoe, the biological life shared by all living species. Since this management, or oikonomia of biological life has been, throughout the western tradition, related to labor, Arendt concludes that totalitarianism became possible once political action was made to serve the animal laborans, rather than vice versa. This reversal of the hierarchy between action and labor, in turn, was facilitated by the Christian transformation of life into the "ultimate good", a belief that modernity, in spite of its secularism, holds on to (Arendt, 1958: 313ff). ${ }^{17}$ But the real question concerns the philosophical basis for Arendt's rejection of the management of biological life as a goal of politics.

Interpreters have taken the above claims as license to make Arendt's conception of politics completely dependent on a separation between "humanized" life (bios) and animal life (zoe) that is of Aristotelian derivation. ${ }^{18}$ Arendt, at times, encourages this interpretation by saying that species or animal life knows no birth or death, whereas human life begins with birth and ends with death (Arendt, 1958: 96). "The biological process in man... [is] endlessly repetitive”(Arendt, 1958: 98), whereas human life in its linearity is an "interruption" of the natural "circle" of life. Actions and words, in turn, are the political events that "mark" the linearity of a human life such that its bios can become the subject matter of a "story" written by those who have witnessed the effects of the actions and words. For Arendt, humans have bio-graphies whereas species do not (Arendt, 1958: 97-8). The implication is that without such a bios politikos, without such actions and words of the actor, retold by the spectators, there is no "self" (Cavarero, 2000). Whereas zoe belongs to the individual qua member of a species, the bios of the individual is something that happens "outside" of the individual, and does not belong exclusively to the individual, but to the in-between that Arendt calls the "world" or the "public space". To be "dead to the world", i.e., to be alive but practice of laboring with no end or purpose in sight (Arendt, 1973: 444f), is further evidence, for Arendt, that the way towards a totalitarian politics of death is prepared by the universalization of the condition of animal laborans in a society of "jobholders", a society in which whoever is so unlucky as to fall into unemployment runs the risk of literally being left to die (Arendt, 1973: 126-135, 322).

18 This is the basic dualism that Ricoeur, among many others, sees at the basis of Arendt's "philosophical anthropology": “naitre, c'est accéder à un monde durable, au lieu de simplement surgir au sein de la répétition sempiternelle de la nature; et mourir, c'est se retirer d'un tel monde durable. C'est au milieu d'un monde humanizé que l'homme nait et meurt. Pour la meme raison, le laps de temps entre la naissance et la mort mérite d'etre appelé 'Bios' et non plus 'Zoe'". (Ricoeur, 1983: 22). For a recent interpretation of Arendt's theory of natality entirely based on the dualism between bios and zoe see (Durst 2004). For a discussion of the biopolitical significance of Aristotle's distinction between bios and zoe see (Agamben, 1998). 
insignificant to those others who alone can judge the significance of our words and acts, is to live a life that "has ceased to be human life because it is no longer lived among men" (Arendt, 1958: 176). Even Collin, whose reading of Arendt is one of the few attempts not to take for granted the dualism between zoe and bios, in the end posits the priority of bios over zoe: "freedom is not freedom against the 'facticity' of birth, from which it should in some ways tear itself free, but freedom is birth. It is the biological which sets itself apart from the biographical, and not the other way round: life as zoe is constructed or constituted on life as bios" (Collin, 1999: 106).

But ascribing to Arendt an Aristotelian distinction between bios and zoe leads to considerable problems when it comes time to giving a coherent account of Arendt's thought. First of all, this distinction leads one to posit a human "nature" that is "political". It suggests that "having" logos and being a "political" animal determine the nature of the animal "man" in distinction to other animal species. But Arendt clearly rejects Aristotle's "naturalization" of politics in the sense of his ascribing the political to human "nature" (Arendt, 2005: 95). Aristotle, like the western political tradition after him up to but not inclduing Hobbes, according to Arendt, misses the basic distinction between "man" and "men", between human nature and the human condition of plurality. It is this plurality of men that first makes possible the in-between of politics, and therefore the in-between cannot possibly be reduced to the bios politikos of man, as Aristotle wants to do.

The second problem with the distinction between zoe and bios is that it does not correspond to anything in Augustine, from whom Arendt draws the idea of natality in the 1950s. Indeed, it is clear from the Denktagebuch that Augustine's own discussion of natality occasioned a problem for Arendt's basic starting point of human plurality, since Augustine, precisely when discussing the reason for God's creation of man, claims that God created human beings as "Adam", that is, as "man" in contrast to the creation of animals, which is always plural. "Jewish-Christian creation myth and the concept of the political: everything hangs on the difficulty to grasp the specific human plurality. Men in contrast to animals ('plura simul iussit existere') descend from One Man ('ex uno homine') and have through this origin 1. the guarantee of their similitude to God, because God is One, and 2. the guarantee that peoples need not degenerate into races (Völker nicht zu Rassen entarten) or simply degenerate. In the 'ex uno homine', in the fact, that plurality is secondary, lies the guarantee of 'humanity'.... (Plurality as animality [das Tierische]!) The state as 'civitas terrena' exists in order to take on our animality in the most humanly dignified way possible, in order to protect men in their being-animal, that is, in their plurality" (Arendt, 2002: 70-71). Given Augustine's starting point, it follows that when plurality is assumed to be a secondary feature of men, as the ideal of "humanity" seems to require, politics becomes identical to the domination of nature and of animality in men. Here is Arendt's closest point of contact with the thesis that Adorno and Horkheimer, only a few years before, presented in their Dialectic of Enlightenment, in which the "rational" control of nature and of instinct, understood as the attempt to escape the mythical, simply proves to be the mythical itself.

One way out of the dilemma could have been for Arendt to rethink the political starting from the emancipation of the animality of human beings, and returning the political back to the plural of the animal. ${ }^{19}$ But Arendt does not take this route and instead opts for what could be called an 
intermediate path that "saves" Augustine from himself, namely, by interpreting the creation of Adam as the creation of man and woman, the origin being two-ness and not the one-ness of a common progenitor of the species, and relating this two-ness to plurality by way of fertility and child-bearing. I analyze this question in detail below. What is important here is to emphasize Arendt's rejection, on political grounds, of the reduction of human plurality to Adam, to the common progenitor of the human race. ${ }^{20}$ For if such a progenitor becomes the model for political association, then this association will never be one that begins from the plurality of men. That is why Arendt has no hesitation in praising Hobbes, and modern contractarian theory in general, for rejecting the Adamic origin of men and replacing it by the state of nature, thus preparing the way for thinking about the political from the originary plurality of individuals who form the in-between by way of compacts (Arendt, 2005: 95). Natality, then, is a concept that Arendt employs to deconstruct the 'humanist' opposition between animality and humanity based on the distinction between zoe and bios, but which nonetheless maintains an internal reference to divine creation that it never loses.

If, notwithstanding her own arguments, Arendt nevertheless lapses, or seems to lapse, into a positive usage of the Aristotelian distinction between bios and zoe in order to distinguish what is a properly "human" from what is an "inhuman" human life, this lapse is undoubtedly motivated by her rejection of the totalitarian selection and annihilation of humanity in order to achieve complete control over biological life in the form of the creation of a "superior" race and having as sole result the "bestialization" of human beings. ${ }^{21}$ But such attempts to counter totalitarian biopolitics simply by means of effecting the separation of humanity from biological life (and, conversely, by ambiguously denying full "humanity" to those "peoples" who are too caught-up in "nature" $)^{22}$ for the sake of distinguishing a purely "human", "highly unnatural” life, only lead her into an unnecessarily harsh version of ideological humanism at one point of her development, and in the end do not correspond to the deepest traits of her thought, which always emphasizes what is most "human" as a condition of the living, and not vice versa. the faithful (that is, the city of God) cannot escape reference to a common descent of the "human race" from one progenitor (Arendt, 1996: 111). Arendt's point is precisely that such a common descent makes it impossible to think of forming a political society based on the plurality of individuals: the society of the faithful (the Church) is a society of a plurality of individuals "isolated" in God's presence, but it is not, for all that, a political society. I disagree with Collin's reading of the dissertation, for whom Arendt's conception of plurality signals the "conjunction" of Augustine's two cities (Collin, 2000: 86).

21 Arendt's "humanist" position, prior to her discovery of the category of natality, is crystallized in the following claim: "Actually the experience of the concentration camps does show that human beings can be transformed into specimens of the human animal, and that man's 'nature' is only 'human' insofar as it opens up to man the possibility of becoming something highly unnatural, that is, a man" (Arendt, 1973: 455). It is interesting that in her analysis of totalitarian domination, which tries to transform "the human personality into a mere thing that even animals are not", Arendt claims that "under normal circumstances this [goal] can never be accomplished, because spontaneity can never be entirely eliminated insofar as it is connected not only with human freedom but with life itself, in the sense of simply keeping alive" (Arendt, 1973: 438). Here Arendt clearly wants to link human freedom to a biological condition, but has not yet identified natality as this condition.

22 See Arendt's ambiguous description and attitude toward the racism of Boers: "the Boers were never able to forget their first horrible fright before a species of men whom human pride and the sense of human dignity could not allow them to accept as fellow-men.... What made them [African peoples which according to Arendt belong to "tribes of which they have no historical record and which do not know any history of their own"/MV] different from other human beings was not at all the color of their skin but the fact that they behaved like a part of nature, that they treated nature as their undisputed master, that they had not created a human world, a human reality.... They were, as it were, 'natural' human beings who lacked the specifically human character" (Arendt, 1973: 192). 
The ideological humanism of Arendt climaxes with the idea, voiced towards the end of The Origins of Totalitarianism, that without "a place in the world", without participation in the political life of some determinate community, human life lacks humanity and dignity. ${ }^{23}$ I take this to be the "humanist" conclusion to which Arendt arrives around 1949, with the first edition of The Origins of Totalitarianism. Paradoxically, this "humanist" conclusion is very critical of the doctrine of human rights as a solution to the problem of genocide and state-less people in general proposed, at least implicitly, by the 1948 Universal Declaration of Human Rights of the United Nations, on the grounds that any doctrine of "human" rights not based on the idea of an "essence" or "nature" of Man is a fragile doctrine, and for Arendt everything at the end of the $20^{\text {th }}$ century conspires against holding on to the idea of a human "essence" or "nature". ${ }^{24}$ On the other hand, in 1949 Arendt has nothing better to propose than a vague defense of some sort of national self-assertion of a people, having in mind, clearly, the events leading to the foundation of the state of Israel as the least inadequate response to the Shoah. ${ }^{25}$ Later, Arendt will become increasingly critical of the Zionist solution and, although never an outright defender of the absoluteness of human rights, she will not repeat again her critique of human rights with the harshness of its first formulation (Isaac, 1996; Parekh, 2004).

It seems, then, that the "humanist" conclusion to the first edition of The Origins of Totalitarianism should be interpreted as a moment of impasse in the development of Arendt's thought. That first edition ends on a tone of hopelessness when faced with the unheard of "novelty" of totalitarianism as a form of rule. For, on the one hand, Arendt maintains that "our political life rests on the assumption that we can produce equality through organization, because man can act in and change and build a common world, together with his equals and only with his equals" (Arendt, 1973: 301). But, on the other hand, "the dark background of mere givenness, the background formed by our unchangeable and unique nature, breaks into the political scene as the alien which in its all too obvious difference reminds us of the limitations of human activity" (Arendt, 1973: 301). Arendt concludes that the political sphere will inevitably tend "to destroy" the "alien" as "frightening symbol of the fact of difference as such" (Arendt, 1973: 301). But, should "a civilization succeed in eliminating or reducing to a minimum the dark background of difference, it will end in complete petrification and be punished, so to speak, for having forgotten that man is only the master, not the creator of the world" (Arendt, 1973: 302). Clearly at this point in the development of her thought Arendt had not found a way to reconcile the natural "fact of givenness", and her belief in "the creator of the world", with a form of political organization that is not, tendentially, vowed to the extermination of the "alien".

"Not the loss of specific rights, then, but the loss of a community willing and able to guarantee any rights whatsoever, has been the calamity which has befallen ever-increasing numbers of people. Man, it turns out, can lose all the socalled Rights of Man without losing his essential quality as man, his human dignity. Only the loss of a polity itself expels him from humanity" (Arendt, 1973: 297).

24 In Origins of Totalitarianism Arendt speaks of "the assumed existence of a human being as such" as the doubtful basis of "the conception of human rights" (Arendt, 1973: 299). A similar scepticism about the existence of a "human nature" or, should it exist, about the possibility of coming to know it, opens The Human Condition (Arendt, 1958: 10-11). Arendt, instead, opts for speaking about the "conditions", as opposed to the "nature", that make a "human" life possible.

25 "Not only did loss of national rights in all instances entail the loss of human rights; the restoration of human rights, as the recent example of the State of Israel proves, has been achieved so far only through the restoration or the establishment of national rights" (Arendt, 1973: 299). 
The impasse of the first edition of The Origins of Totalitarianism explains why Arendt, after its publication, still thought that she had not fully "understood" totalitarianism, since she had not found out whether anything could be "done" about it. This explains why some of her first important essays after The Origins of Totalitarianism, such as "Understanding and Politics" and "On the Nature of Totalitarianism" (Arendt, 1994), are centered on the problem of "understanding" totalitarianism in relation to the need of completely renewing the traditional doctrine of the "forms of government" inherited since Plato and Aristotle. But her thinking anew about human political organization would have been incomplete if she had not found, in the concept of natality, the way to reconcile life with politics. ${ }^{26}$ It is highly significant, therefore, that Arendt would define understanding as "the specifically human way of being alive; for every single person needs to be reconciled to a world in which he was born a stranger and in which, to the extent of his distinct uniqueness, he always remains a stranger" (Arendt, 1994: 308).

If hopelessness still lingers in The Human Condition, it does so to the extent that this book lets itself be interpreted as if it were putting forward the "humanistic" thesis that without a life in a polis, the human individual can never reach his or her "full" humanity. ${ }^{27}$ But the claim that the point of The Human Condition is simply to defend the priority of the Greek bios politikos against the revaluation of labor and of the worker in modernity must be rejected. This cannot be the point of the book precisely because in it Arendt wants to think politics from the idea of natality, and she expressly says that natality is not a category of Greek political thought, and that it is the only source of hope against totalitarianism (Arendt, 1958: 247). ${ }^{28}$

Natality is the condition for a world and for the political, but it is a condition that does not depend on the previous existence of an organized political space; that is, natality is the concept through it which it becomes possible to think the political independently from the Aristotelian claim that the political or the polis is "natural" to man, yet still as a function of life itself. The "naturalness" of the political was of decisive importance in the development of western political thought, both in antiquity, and in the late medieval recovery of Aristotle. But for Arendt, unlike her contemporaries

"The result of understanding is meaning, which we originate in the very process of living insofar as we try to reconcile ourselves to what we do and what we suffer"(Arendt, 1994: 309). Here the accent must fall in the radical refusal to separate "understanding" from "process of living", and, equally, on the need to reconcile oneself to the limitations of action by recognizing "what we suffer".

27 Such a reading of Arendt characterizes the early reception of The Human Condition and still weighs on interpretations like the one suggested by (Benhabib, 1996), who sees, precisely in the presumed attachment of Arendt to the polis-experience, the root of her "reluctant" modernism. In this context it is interesting to consider the exchange between Jaspers and Arendt occasioned by her biography of Rahel Varnhagen, in the letters from August 23, 1952 and September 7, 1952. Arendt responds to Jaspers as follows: "You're absolutely right when you say this book 'can make one feel that if a person is a Jew he cannot really live his life to the full.' And that is of course a central point. I still believe today that under the conditions of social assimilation and political emancipation the Jews could not 'live'. Rahel's life seems to me a proof of that precisely because she tried out everything on herself without attempting to spare herself anything and without a trace of dishonesty. What always intrigued me about her was the phenomenon of life striking her like 'rain pouring down on someone without an umbrella'". (198) What is interesting in Arendt's response, in my terms, is her attempt to think the negation of life, the 'lack' of life as experienced by an assimilated Jew in the $18^{\text {th }}$ and $19^{\text {th }}$ century, by referring to "the phenomenon of life" itself, rather than by appealing to some value or sphere beyond life itself. That is why Arendt both picks up on Jaspers intention, but changes its meaning by dropping his idea of a "full" life not accessible to Jews as Jews. By this time, Arendt had begun to find the way out of the impasse at the end of The Origins of Totalitarianism.

28 On Arendt's messianism and its connection to Benjamin's idea of a "weak messianic force" see now (Gottlieb, 2003: 135-160). 
living in Chicago, Leo Strauss and Jacques Maritain, this political paradigm had nothing left to offer against the onslaught of totalitarian politics. It was crucial, therefore, that natality be able to function where the world has become a "desert", for totalitarian society mobilizes the lonely crowds as if "setting the desert itself in motion". ${ }^{29}$ The reason natality can function even in "desert storms" is because natality names the primordial "nomadic" condition of human life. ${ }^{30}$

Most readings of natality found in the literature are problematic precisely because they presuppose that one is born "into" the world, as if this in-between were already given previously to the fact of natality and always already contained natality. ${ }^{31}$ But the idea of being born into anything like an "identity by birth" (Durst, 2004: 787) goes profoundly against the grain of Arendt's sense of the desert that the world can always become. It also goes against her equally crucial reading of Abraham (Arendt, 1958: 243) (Arendt, 1990: 172), for whom the crossing of the desert has nothing to do with the "family" one is born into, but rather with the possibility of establishing the contract with, and the promise to, the other as basic political phenomena, precisely unrelated to the family and even less to love. ${ }^{32}$ Natality is the key category for a politics that is to come after

In "Ideology and Terror" she defines totalitarianism as a movement akin to a "sandstorm" started by "teaching and glorifying the logical reasoning of loneliness where man knows that he will be utterly lost if ever he lets go of the first premise from which the whole process is started" (Arendt, 1973: 478).

30 The idea that we are born into a world that is primordially a "desert" is very old in Arendt. In her dissertation she speaks of "the particular strangeness in which the world as a 'desert' pre-exists for man" (Arendt, 1996: 67). In a fragment of 1955 she speaks of the "threat" posed to the world as in-between by natality. And then adds, "in its need for beginners that it may be begun anew, the world is always a desert" (Arendt, 2005: 203).

31 Examples of the tendency of thinking natality as always already contained within the world abound: "a birth happens to the being who is born.... It is invariably already human because it is always welcomed by human beings, caught in a narrative which questions it.... It is immediately the child of words - the child of the Word as much as of the flesh" (Collin, 1999: 107); "the question of beginning, of natality, is ultimately linked to one's sense of communal identity, that is to say, linked to one's sense of belonging and to one's way of comporting oneself in a world inhabited by and shared with others" (Bowen-Moore, 1989: 9); "the world which receives us into it and makes us feel welcome is not the world objectified by natural science but a phenomenological world, a world of human doings, of affairs of men in association with one another, of sights and sounds appropriate to a fitting human dwelling” (Beiner, 1984: 362); “the weakness of the parvenu and the strength of the pariah depend on how much they received or did not receive with birth, that is, having or not having had the possibility to benefit from the experience of 'feeling at home'. Heimatgefühl constitutes the intimate nucleus of the personal identity that functions as "first root'" (Durst, 2004: 785); "natality is the condition through which we immerse ourselves into a world at first through the goodwill and solidarity of those who nurture us.... The condition of natality involves inequality and hierarchies of dependence" (Benhabib, 1996: 196). A welcome exception is (Tassin, 1999) who clearly sees the tension between natality and world-building. That natality does not "destine" the individual to a given world is what Tassin refers as the "acosmism" of Arendt's conception of freedom. But Tassin does not relate this "acosmism" further to Arendt's theological foundation of her concept of natality.

32 (Dietz, 1995) and (Pitkin, 1998) both reject, against some previous feminist readings of Arendt, the claim that her concept of action and of politics is "gendered", in the sense that the public sphere would be predetermined as masculine in opposition to the feminine private sphere. On the other hand, both seem to argue that Arendt's concept of labor is gendered because of the strong association Arendt makes between labor and giving birth (Pitkin, 1998: 166). Whatever Arendt may have thought about the family, she never associates natality with the house-hold or with child-rearing. Natality is the reason for the existence of politics, it is not the reason for the existence of the family. This is clear from her rejection of all attempts to root the political in the presumed "need" that human beings have to live together in order to take care of necessities. If natality is associated to labor in Arendt, it is only in the sense that the politicization of labor should emancipate it from the strictures of the family. "The great, enormously great and entirely unrecognized merit of Marx: having grounded public life and the being of man on labor and not on the family. The emancipation from the spell of labor and the tyranny of the family. The emancipation of property as a basis of political life is merely a consequence of the emancipation of the political from the family" (Arendt, 2002: 71) 
the end of the nation-state, after all the illusions of the earth as a Heimat are laid to rest, after all attempts to think the political starting from or returning to the familial have shown their barrenness, and, perhaps, even after the passing away of all political form or organization as such.

In reality, Arendt's conception of natality does not presuppose the Aristotelian dualism between zoe and bios, but thematizes its limits and ultimately overthrows its sense. Arendt repeatedly claims that natality is not only what "inserts" life into a pre-given world, but that natality is also what "daily renews" this world itself, which otherwise would perish along with the death of individuals (Arendt, 1958: 246-7; Arendt, 2003: 49). Properly understood, this claim means that natality is irreducible to the bios politikos: natality is essentially antecedent with respect to the common world. To understand its meaning, one must bring the concept of natality back to the level of zoe and ask what difference does natality make within and for biological life (zoe). In sum, if in Arendt there is a "positive" conception of biopolitics, it will depend on conceiving natality as a politicization of zoe, not of an always already "political" bios. This politicization of life goes in the opposite direction of what Esposito calls "the cycle of ghenos (descent, race)", and what Forti has analysed in the "biopolitics of the soul" characteristic of Nazism, that is, opposite to a biopolitics whose supreme goal is the fabrication of a "good" descent or race, a eu-genic biopolitics. If something like a bios politikos and a vita activa can survive in the posttotalitarian age, it will not depend on keeping politics apart from life and labor, as Arendt has all too often been misinterpreted, but, on the contrary, it will depend on knowing how to politicize life and labor, and only these, ${ }^{33}$ so that they may avoid becoming the targets of domination and the media of a politics of death. ${ }^{34}$

\section{NATALITY AS CONDITION OF FREEDOM}

For Arendt a human life is a free life. Natality is fundamental to Arendt's idea of politics because she believes that freedom is the only meaning (Sinn) of politics (Arendt, 2003: 31ff). And natality is the "condition" of such political freedom. The central questions of Arendt's political thought after 1950 become: What is freedom? Why does freedom need to be conditioned by natality? Her answer has two components. The first is that freedom must be worldly and not private. This requirement, in my opinion, comes from her presupposition, of Heideggerian origin, that there is

33 In a note from December 1952, Arendt comments on Aristotle's passage that distinguishes "living" from "living well”, and asks herself: "Marx: what happens if instead of logon echon one places the 'laboring' (=producing) living being? Marx never doubted about the animality (das Animalische) in the definition 'animal rationale'. Through the concept of labor he attempts to connect immediately what is specifically human to the animal. That means, mutatis mutandis, to derive freedom from necessity.... The Greeks do the opposite: they 'derive' freedom out of the 'rational' or violent domination of the necessary. This is one of the reasons why the logos becomes tyrannical.... Eu zen= to live in freedom= to dominate tyrannically over necessity" (Arendt, 2002: 280-281). If one recalls that Arendt always opposes freedom to the "tyranny" of logic, it becomes clear that in the above passage she sides with Marx's attempt to politicize life through a new conception of labor, against the Greek solution.

34 On this reading, the old debate as to whether Arendt is "nostalgic" for the Polis or, instead, merely a "reluctant" modernist is shown to be completely besides the point. Conversely, her attack on Marx for having politicized labor and life can be analyzed as an attempt to distinguish her own position from someone with whom she felt herself uncomfortably close - this closeness is manifest in Arendt's defense of the communes as the form of government of the future (of a democracy to-come, Derrida would say), opposed to the present form of government, i.e., totalitarian government (Arendt, 1990). 
no "private" meaning (Sinn), that what gives meaning simply is the world as a totality of interlocking references. ${ }^{35}$ But she was to develop this insight, against Heidegger, through her theory of "common sense", her revaluation of doxa, and her theory of judgment (Arendt, 1978, 1982, 2005). So one component of freedom must be that it exists for and before others; that it takes place in-between individuals; in short, that freedom be "phenomenalizable". The requirement of phenomenality is so decisive for Arendt that it leads her to consider freedom of movement as the fundamental freedom: movement through an "open" space is the most basic phenomenalization of freedom. ${ }^{36}$

But if this explains why freedom could be seen as the Sinn of politics, it does not answer the question of what freedom is. The concept of freedom in Arendt has three essential features. The first is a Kantian feature: the idea that freedom is spontaneity. "Action is unique in that it sets in motion processes that in their automatism look very much like natural processes, and action also marks the start of something, begins something new, seizes the initiative, or, in Kantian terms, forges its own chain. The miracle of freedom is inherent in its ability to make a beginning" (Arendt, 2005: 113). What needs to be emphasized about this definition is that the capacity to begin a new series of events has an "automatism" that is analogous to the one found in natural processes, but unlike it in the sense that freedom is the automatism of an interruption of natural processes. Natality is not just an "interruption" of the natural process, but it is an "automatic" interruption of it.

The importance of the automatism of beginnings becomes apparent when related to Arendt's fundamental claim that totalitarianism makes singular individuals superfluous through the systematic, even bureaucratic application of laws of Nature or History intended to produce one Humanity or Mankind, i.e., intended to turn the plurality of men into the species Man. "The law of Nature or the law of History, if properly executed, is expected to produce mankind as its end product.... Terror... makes it possible for the force of nature or of history to race freely through mankind, unhindered by any spontaneous human action" (Arendt, 1973: 461, 465). Natality is what stands in the way of achieving, of finalizing the human species because, according to Arendt, natality only brings forth singulars, radically diverse individuals, but no species "Man".

On her view, if one may speak of a "human" species at all, it is only as a result of the "multiplication" of singulars, that is, only on the basis of the biological "fertility" of a life that has been previously singularized by natality. The treatment of natality in The Human Condition begins with

35 See Heidegger's definition of world as referential totality in Sein und Zeit: "The relational totality of this signifying we call significance. It is what makes up the structure of the world" (Heidegger, 1986: 87). Obviously the question of the "meaning of politics" that structures Arendt's Was ist Politik? mimics Heidegger's SZ pursuit of the "Frage nach dem Sinn von Sein". Yet for Arendt this pursuit of the "Sinn" (meaning) of politics is also and explicitly carried on against existentialism, as shown by her critical essays on French and German existentialism of the same period (Arendt, 1994). The crucial difference between the Heideggerian-existentialist pursuit of meaning, and the Arendtian one, is that Heidegger still has in Sein und Zeit a pre-linguistic, subjectivistic conception of meaning, as shown now by (Lafont, 2000: 11-84), whereas for Arendt the question of meaning is always already linguistic and so intersubjective: there is no re-vealing or appearing of something as something prior to and without speech.

36 On the conditions of phenomenalization and singularization, and their internal limits, see (Schürmann, 1996). But Schürmann interprets Arendt's natality as a principle of phenomenalization only; whereas he follows Heidegger in the belief that mortality, not natality, is the counter-principle of singularization. I argue, instead, that Arendt's natality also serves as a principle of singularization. Plurality, rather than mortality, functions for her as principle of phenomenalization. 
the idea of plurality as "the fact that men, not Man, live on the earth" (Arendt, 1958: 7), which Arendt glosses by referring to the passage in Genesis I: 27 where it is written that God created "them", male and female, and not just "him" (adam). Creation gives singularity, and men come out of this plural singularity as the result of "multiplication", i.e., of life on earth, and the "fertility" of this earthly life (Arendt, 1958: 8). The crucial point for Arendt is that createdness, not fertility, is the root of singularity. Fertility is merely the cause of the multiplication of singulars. "The force of life is fertility. The living organism is not exhausted when it has provided for its own reproduction, and its 'surplus' lies in its potential multiplication" (Arendt, 1958: 108). In this sense, Arendt modifies what she had said in Fragment 1 of Was ist Politik?: men owe their plurality not to themselves, but to the fertility of life on earth; they have God's creation to thank not for their species, but for their existence as singulars. Singularity in The Human Condition is specifically opposed to species-life: labor "assures the life of the species" but not the existence of the singular, "the constant influx of newcomers who are born into the world as strangers" (Arendt, 1958: 9).

The natural fertility of biological life, as well as the natural surplus of labor are never opposed to natality in Arendt, because this fertility makes "automatic" the singularization of life achieved through natality. In order to counter the biopolitics of totalitarianism that seeks to generate the species Man by applying law directly to life, i.e., by eugenically and genocidally regulating fertility and labor so as to make the singularization of life superfluous, Arendt opposes natality as the automatic singularization of life. In The Origins of Totalitarianism Arendt showed that singulars cannot be made superfluous without at the same time making positive law and legal rights superfluous to the application of Justice, that is, to the exception-less application of Laws of Nature and History, since positive law and legal rights are for her the only possible equality that singulars can mutually give to each other and recognize in each other. In The Human Condition, she argues that freedom requires the automatism of life while remaining counter-natural, where "natural" means subsumed under a law-like process. Natality is the only category that satisfies both of these, apparently contradictory, conditions: belonging to life yet not subsumable under a rule or law (and hence "miraculous"). Being born is an "automatic" feature of human life on earth, and this means that what is inserted through birth into the world must remain unlawlike and exceptional in two related senses: natality must bring forth singular, completely unique individuals, and these singulars themselves must be beginners, that is, origins of spontaneous interruptions of law-like behavior.

Ultimately, Kant is less important than Augustine for Arendt's conception of freedom for several reasons. The definition of freedom as spontaneity is valuable to her insofar as it makes clear that the spontaneous beginning is an "interruption" of a natural series of conditioned conditions, i.e., freedom is not conditioned by anything natural. But this definition of Kant's is not so valuable for Arendt in so far as it assumes that spontaneity is an unconditioned condition, and, furthermore, that this unconditioned cause is noumenal, i.e., tied to an idea or fact of reason, and therefore radically separated from the sphere of life. What Arendt needs, instead, is a counter-natural yet living condition of human freedom. For her, freedom needs to be a conditioned condition, and yet not be merely an object, a piece of nature, as all conditioned conditions are in Kant's ontology.

Freedom needs to be a non-objective, yet conditioned, condition for a couple of reasons. First, Arendt requires that freedom be existential and not merely noumenal. Freedom must be able to be experienced, lived, and not merely thought. Otherwise, freedom would cease to be "political", 
i.e., it would have no "sense", no phenomenality. ${ }^{37}$ Freedom acquires phenomenality in Kant only in the beautiful (the symbol of the moral), which is the object of judgment, not cognition. Hence, Arendt is led towards Kant's theory of judgment only because of her interest in the phenomenality of freedom. Second, Arendt requires that freedom have a living condition in order to counter the politically very dubious understanding of freedom in Heidegger, which is associated to the experience of resoluteness before one's being-towards-death, an understanding of freedom that Arendt criticizes in her essays on Heidegger and existentialism in the 1950s.

The second essential feature of Arendt's conception of freedom is no longer Kantian because it deprives freedom of unconditionality by making it conditional on natality. I call this second feature of freedom Benjaminian. "With word and deed we insert ourselves into the human world, and this insertion is like a second birth, in which we confirm and take upon ourselves the naked fact of our original physical appearance. This insertion is not forced upon us by necessity.... Its impulse springs from the beginning which came into the world when we were born and to which we respond by beginning something new on our own initiative" (Arendt, 1958: 176-7). If freedom were unconditioned it could not be phenomenalized, and that would mean that it could not be plural: at best, it would be the freedom of humanity, but never the freedom of human beings, of singulars. By making natality into a condition of action, freedom is no longer unconditioned, and yet, in what is only apparently a paradox, this finitude of freedom only reinforces and intensifies it.

Action and natality, conditioned and condition, stand in what may be called a "mimetic" relation with respect to each: action can only be the intensification of natality, and never its limitation, control or domination. ${ }^{38}$ Although a condition of action, natality is responsible for the uncontrollable character of action, which Arendt describes in terms of its "boundlessness" (Arendt, 1958: 190). As the intensification of natality, action occasions new actions in others, and thereby "confirms" the natality of others. "Since action acts upon beings who are capable of their own actions, reaction, apart from being a response, is always a new action that strikes out on its own and affects others"(Arendt, 1958: 190). That is why action qua beginning is not only conditioned by natality but, in turn, conditions natality. ${ }^{39}$ an idea of reason.

38 Arendt speaks of dramatic mimesis as the only way in which "the living flux of acting and speaking can be represented" (Arendt, 1958: 187). But my use of "mimetic" in this context is derived from the sense that Benjamin, and then Adorno, gave to this term, where mimesis stands for a non-representational relation, that Benjamin calls a "nonsensuous similarity" (Benjamin, 1999: 696). It is interesting to note that Benjamin associates the "mimetic faculty" to natality: "If, however, mimetic genius was really a life-determining force for the ancients, then we have little choice but to attribute full possession of the gift, and in particular its perfect adaptation to the form of cosmic being, to the newborn. The moment of birth, which is decisive here, is but an instant. This directs our attention to another peculiarity in the realm of similarity. The perception of similarity is in every case bound to a flashing up" (Benjamin, 1999: 695).

In a recent article on natality, Patchen Markell has provided an interesting interpretation of what I call the mimetic relation between natality and action, one that emphasizes the "responsive" character of action to its condition of natality. His claim is that "we can also understand the relationship of beginning to birth in Arendt by seeing 'birth' as the paradigmatic case of an 'event' to which the actor responds" (Markell, 2006: 7). Natality "is that in virtue of which the actuality of events acquires its weight" (Markell, 2006: 7). For Markell, the crucial character of action lies in its being always already a "response" to the givenness of an event, a response that signals the significance of this event for the actor. That is why Markell, somewhat surprisingly, argues that "nothing about beginning requires a break with the terms of an existing order, or resistance to regularity as such". All that beginning reflects is "a stance 
The third and last essential feature of Arendt's conception of freedom is Augustinian. In The Human Condition Arendt ends her discussion of natality with the following claim: "With the creation of man, the principle of beginning came into the world itself... the principle of freedom was created when man was created but not before" (Arendt, 1958: 177). Natality, the condition of human freedom, is itself conditioned by an act of divine creation. But does this mean that freedom comes to life from a sphere that lies outside of biological life itself? Does God function here as the ultimate guarantor of the separation of human bios from species zoe? Is Arendt's conclusion that men cannot and should not create Mankind because that would be equivalent to usurping God's prerogative? All of these are possible readings of Arendt's constant reference to divine creation, usually ignored by the secondary literature, which fit together with what I called above the "humanist" interpretation of her political thought. But another reading of divine creation in Arendt is also possible, one that fits better with what I have tried to show so far, namely, that Arendt's conception of natality is not "humanist".

Arendt suggests that God creates the human species so that life might have a beginning (i.e., the moment of natality) and be about beginning (in so far as individuals respond to their condition of natality and intensify this condition by acting, and finally these actions or beginnings become the subject matter of stories that transmit their significance to future generations). It is important to note that this formulation of the Augustinian moment of natality in The Human Condition is different from the one cited at the beginning of the essay, and found in The Origins of Totalitarianism. In the version of The Origins of Totalitarianism Arendt does not linger on the point of createdness; nor does she linger on the question of man. The later formulation, instead, gives rise to the question: what exactly is created about man? Is it man's faculty to begin, his creativeness, guaranteed by his creatureliness? Is it man's 'humanity' that is created? Or is it man's biological life?

The answer is that for Arendt neither is the case. Rather, the creation of man gives to natural life its freedom and what can be named its "afterlife". Natality naturalizes history as much as it historicizes nature. The creation of man, then, is to be understood exclusively as a function of the emancipation or redemption of nature, an emancipation that nature cannot achieve out of itself. Arendt here is extremely close to the central thesis put forward by Adorno and Horkheimer, itself derived from Benjamin:

"In the self-cognition of the spirit as nature in disunion with itself, as in prehistory, nature calls itself to account; no longer... with the alias that signifies omnipotence, but as blind

of practical engagement with events" (Markell, 2006: 7). Thus action or beginning is always already "our attunement to its [the event's] character as an irrevocable event, which also means: as an occasion for response" (Markell, 2006: 10). The problem with this reading is twofold: it seems to deprive natality of its status as "ontological root" of action because it turns action into a matter of taking or not taking an intentional "stance" towards the actuality of events, and thus something that we can choose to adopt or not to adopt. Arendt's theory of action receives in this way an occasionalist interpretation. The second problem with Markell's reading is that natality comes to represent, in the life of the individual, merely its openness to "the constellation of circumstances, events and forces, to which each new act is a response" (Markell, 2006: 10). Natality here loses the crucial feature of being the condition of human life that pulls, in and through its reference to the absolute past of creation, every actor out of its captivation to the present circumstances. In Markell natality becomes the source of a "latent self" found in the present circumstances of our life, that we can only make "patent" through our actions. Action would then merely reflect what one understands to be one's "place in the world", where this place is pre-given with respect to the in-between individuals constitute in and through their actions and words. 
and lame. The decline, the forfeiture, of nature consists in the subjugation of nature without which spirit does not exist. Through the decision in which spirit acknowledges itself to be domination and retreats into nature, it abandons the claim to domination which makes it a vassal of nature" (Horkheimer, 1972: 39-40).

The Augustinian sense of natality is always already inscribed within Arendt's Benjaminian critique of Heidegger. This critique opposes the creatureliness of man, the radical immanence of man in nature, to the finite transcendence of Dasein (Benjamin, 1985). The reference to divine creation in Arendt's concept of natality indicates that origin toward which natality tears life out of life (zoe) in order to throw it into the world, but not before having singularized it. Natality is the caesura of life that turns men into creatures, linking the "fallenness" of nature directly to creation and redemption. In the awareness of being creatures, individuals not only understand that they are ultimately strangers in the world, that is to say, that no national or ethnic identity (nascio-) can ever cor-respond to their natality, but also that they exist only as the subjectivity of life itself. Natality, by giving birth to singulars, is the freedom of biological life. Political action, in so far as it intensifies the condition of natality, is to be understood exclusively in terms of the freeing of life, and in opposition to the totalitarian attempt to dominate biological life by dehumanizing it, that is, by eliminating its singularity. This is what Arendt means when she pointedly refers to action as "the redemption of life" (Arendt, 1958: 236). Totalitarianism has therefore nothing to do with a return of "nature" or "barbarism" amidst civilization, but, analogously to what Adorno and Horkheimer argue, totalitarianism is itself anti-natural. Its mythical quality is simply the confirmation that just as "myths already realize enlightenment, so enlightenment with every step becomes more deeply engulfed in mythology" (Horkheimer, 1972: 11).

Arendt therefore rejects the totalitarian dehumanization of human life neither on the basis of a belief in human "nature" (of Aristotelian and Thomistic derivation) nor on the basis of a belief in the Kantian ideal of "humanity" or human "dignity", but on the grounds that to deprive life of the existence of singular human beings is to deprive life of its natality, of its chance to be free. Both the neo-Aristotelian and the neo-Kantian readings of Arendt have to be set aside. The legitimacy of politics in the post-totalitarian age derives from the possibility of emancipating life from its domination. The ultimate ground of this domination of life is the curiously anthropomorphic desire of human beings to become an "animal" species of their own by becoming "human and nothing but human" (Arendt, 1973: 297).

The chance that human natality constitutes for nature is, according to Arendt, rooted in the divine creation of man by God, but it is not a chance that is under the control or providence of God. God completes His creation and withdraws His providence from life precisely at the threshold constituted by the possibility of a free life. And that is why Arendt can consistently maintain both that it makes no sense to speak of natality without divine creation, and that God has nothing to do with politics (Arendt, 2005: 95-6). It is with the same consistency that she claims, in a letter to Jaspers on the radical evil of our times, that "on the personal level, I make my way through life with a kind of (...) trust in God.... There's nothing much you can make of that, of course, except be happy. All traditional religion as such, whether Jewish or Christian, holds nothing whatsoever for me anymore. I don't think, either, that it can anywhere or in any way provide a basis for something so clearly political as laws" (Arendt, 1992: 166). 
There remains one fundamental question that Arendt, as far as I can determine, never addressed in her writings: what is the phenomenological evidence that the fact of being born, the condition of natality, reveals man's creatureliness, i.e., his createdness, and therefore leads to "trusting" in the existence of a Creator? It seems that this last assumption on the part of Arendt is entirely a matter of "faith", and relates her biopolitics to an entirely different discourse, namely, a negative political theology. ${ }^{40}$

\section{REFERENCES}

Agamben, Giorgio. 1998. Homo sacer. Sovereign Power and Bare Life. Stanford: Stanford University Press.

Agamben, Giorgio. 1999. Remnants of Auschwitz. Homo sacer III. The Witness and the Archive. New York: Zone Books.

Agamben, Giorgio. 2000. Means without End. Notes on Politics. Minneapolis: University of Minnesota Press.

Agamben, Giorgio. 2004. The Open: Man and Animal. Stanford: Stanford University Press.

Arendt, Hannah. 1958. The Human Condition. Chicago: University of Chicago Press.

Arendt, Hannah. 1973. The Origins of Totalitarianism. New York: Harcourt, Brace \& Company.

Arendt, Hannah. 1977. Between Past and Future. Eight Exercises in Political Thought. New York: Penguin Books.

Arendt, Hannah. 1978. The Life of the Mind. New York: Harcourt, Brace and Jovanovich.

Arendt, Hannah. 1982. Lectures on Kant's Political Philosophy. Chicago: University of Chicago Press.

Arendt, Hannah. 1990. On Revolution. New York: Penguin.

Arendt, Hannah. 1994. Essays in Understanding 1930-1954. Formation, Exile, and Totalitarianism. New York: Schocken Books.

Arendt, Hannah. 1996. Love and Saint Augustine. Chicago: University of Chicago Press.

Arendt, Hannah. 2002. Denktagebuch: 1950 bis 1973. Muenchen: Piper.

Arendt, Hannah. 2003. Was ist Politik? Fragmente aus dem Nachlass. Muenchen: Piper.

Arendt, Hannah. 2005. The Promise of Politics. New York: Schocken Books.

Arendt, Hannah and Jaspers, Karl. 1992. Hannah Arendt Karl Jaspers Correspondence 1926-1969. New York: Harcourt Brace \& Company.

Aristotle. 1988. Politics. Cambridge: Cambridge University Press.

Augustine, Saint. 1984. The City of God. New York: Penguin.

Beiner, Ronald. 1984. "Action, Natality and Citizenship: Hannah Arendt's Concept of Freedom". In Conceptions of Liberty in Political Philosophy, edited by J. Pelczynski and J.Gray. London: Athlone Press, 349-375.

Benhabib, Seyla. 1996. The Reluctant Modernism of Hannah Arendt. London: Sage.

Benjamin, Walter. 1968. Illuminations. New York: Schocken Books.

Benjamin, Walter. 1985. The Origin of German Tragic Drama. London: Verso.

Benjamin, Walter. 1999. Selected Writings. Volume 2 1927-1934. Cambridge, Massachusetts: The Belknap Press of Harvard University Press.

Benjamin, Walter. 2002. Selected Writings. Volume 3 1935-1938. Cambridge: Harvard University Press.

Bowen-Moore, Patricia. 1989. Hannah Arendt's Philosophy of Natality. New York: St. Martin's Press.

Brunkhorst, Hauke. 1999. Hannah Arendt. Muenchen: Beck.

Canovan, Margaret. 1994. Hannah Arendt: A Reinterpretation of Her Political Thought. Cambridge: Cambridge University Press.

Cavarero, Adriana. 2000. Relating Narratives: Storytelling and Selfhod. London: Routledge.

Collin, Francoise. 1999. "Birth as Praxis". In The Judge and the Spectator: Arendt's Political Philosophy, edited by J.Herman and D.Villa. Belgium: Peeters, 97-110.

Collin, Francoise. 2000. "Nacer y tiempo. Agustín en el pensamiento arendtiano”. In Hannah Arendt. El orgullo de pensar, edited by Fina Birulés. Barcelona: Gedisa.

Deleuze, Gilles and Felix Guattari. 1987. A Thousand Plateaus: Capitalism and Schizophrenia. Minneapolis: University of Minnesota Press.

40 The withdrawal of God from politics, and Arendt's critique of any attempt to base the plurality of human beings on the oneness of God, lies at the root of her negative political theology, which I hope to discuss in the a companion piece to this article relating her thought to Benjamin's. 
Dietz, Mary. 1995. “Feminist Receptions of Hannah Arendt”. In Feminist Interpretations of Hannah Arendt, edited by Bonnie Honig. University Park, PA: Pennsylvania State University Press.

Duarte, André. 2004. "Biopolitics and the Dissemination of Violence: The Arendtian Critique of the Present". Pasajes de Pensamiento Contemporáneo 13. An English version can be accessed online at HannahArendt.net, Research Notes (April 2005).

Durst, Margarete. 2004. "Birth and Natality in Hannah Arendt". Analecta husserliana 79: 777-797.

Esposito, Roberto. 2004. Bios. Biopolitica e filosofia. Turin: Einaudi.

Forti, Simona. 1996. Vita della mente e tempo della polis: Hannah Arendt tra filosofia e politica. Milan: Franco Angeli.

Forti, Simona. 2003. I/ totalitarismo. Roma-Bari: Laterza.

Forti, Simona. 2006. "The Biopolitics of Souls. Racism, Nazism, and Plato". Political Theory 34: 9-32.

Foucault, Michel. 1990. The History of Sexuality. Volume I: An Introduction. New York: Vintage Books.

Foucault, Michel. 2004. Naissance de la biopolitique. Paris: Gallimard Seuil.

Freud, Sigmund. 1961. Beyond the Pleasure Principle. New York: W.W. Norton \& Company.

Gottlieb, Susannah. 2003. Regions of Sorrow. Stanford: Stanford University Press.

Heidegger, Martin. 1986. Sein und Zeit. Tuebingen: Max Niemeyer.

Heller, Agnes and Ferenc Feher. 1994. Biopolitics. Vienna: European Centre.

Horkheimer, Max and Theodor W. Adorno. 1972. Dialectic of Enlightenment. New York: Continuum.

Isaac, Jeffrey C. 1996. "A New Guarantee on Earth: Hannah Arendt on Human Dignity and the Politics of Human Rights". The American Political Science Review 90 (1): 61-73.

Kristeva, Julia. 2000. El genio femenino. 1 Hannah Arendt. Buenos Aires: Paidós.

Lafont, Cristina. 2000. Heidegger, Language, and World-Disclosure. New York: Cambridge University Press.

Lemm, Vanessa. 2004. “The Overhuman Animal”. In A Nietzschean Bestiary. Becoming Animal Beyond Docile and Brutal, edited by Christa Davis Acampora and Ralph Acampora. New York: Rowman \& Littlefield Publishers, 220-242.

Lemm, Vanessa. 2006. "Memory and Promise in Nietzsche and Arendt". Revista de Ciencia Política 26 (2): 161-173.

Levi, Primo. 1996. Survival in Auschwitz. The Nazi Assault on Humanity. New York: Simon and Schuster.

Markell, Patchen. 2006. "The Rule of the People: Arendt, Arche, and Democracy". The American Political Science Review 100 (1): 1-14.

Parekh, Serena. 2004. "A meaningful place in the world: Hannah Arendt on the nature of human rights". Journal of Human Rights 3 (1): 41-53.

Pitkin, Hannah Fenichel. 1998. The Attack of the Blob. Hannah Arendt's Concept of the Social. Chicago: University of Chicago Press.

Ricoeur, Paul. 1983. "Préface”. In Hannah Arendt. Condition de l'homme modern. Paris: Calmann-Lévy, 5-39.

Savarino, Luca. 1997. Politica ed estetica. Turin: Silivio Zamorani editore.

Savarino, Luca. 2003. "Hannah Arendt e l'antropologia filosofica”. Discipline filosofiche vol 13: 215-237.

Schürmann, Reiner. 1996. Des hégémonies brisées. Mauvezin: Trans-Europ-Repress.

Szankay, Zoltán. 1995. “Arendtsche Denkungsart und Oeffnungsweisen der 'Demokratischen Frage'”, http://polylogos. org/philosophers/arendt/arendt-democratic.html (accessed December 11, 2006).

Taminiaux, Jacques. 1985. "Arendt, disciple de Heidegger?" Etudes phénoménologiques 2: 111-136.

Tassin, Étienne. 1999. “L'azione 'contro' il mondo. II senso dell'acosmismo”. In Hannah Arendt, edited by Simona Forti. Milan: Bruno Mondadori, 136-154.

Villa, Dana. 1996. Arendt and Heidegger: The Fate of the Political. Princeton: Princeton University Press.

Weber, Samuel. 2005. Targets of Opportunity. On the Militarization of Thinking. New York: Fordham University Press.

Miguel Vatter es profesor adjunto ordinario del Instituto de Ciencia Política de la Pontificia Universidad Católica de Chile. Es autor de Between Form and Event: Machiavelli's Theory of Political Freedom (Kluwer, 2000), y de artículos sobre teoría democrática contemporánea e historia de las ideas políticas. 
